\title{
Pulmonary oedema precipitated by cold water swimming
}

\section{R Biswas, P K Shibu, C M James}

Br J Sports Med 2004;38:e36 (http://www.bjsportmed.com/cgi/content/full/38/6/e36). doi: 10.1136/bjsm.2004.012138

The case is reported of a physically fit man, who, while training for a triathlon, developed pulmonary oedema secondary to swimming in cold water. Pulmonary oedema is usually caused by a combination of exercise and cold water, resulting in an increase in cardiac preload and after load, which causes an increase in pulmonary capillary pressure. Most cases improve spontaneously and quickly with no recurrence of symptoms.

\section{CASE REPORT}

A 36 year old man was admitted to our hospital complaining of shortness of breath and haemoptysis. He was physically fit and training for a local triathlon competition when the problem occurred. He had been swimming in the sea, wearing a wet suit, for about 10 minutes when he started to feel slightly short of breath. He loosened his wet suit and let the cold water in. However, his breathing worsened. He continued to swim for half a mile more. He started to cough up blood stained sputum. He returned to the shore at this stage and was more short of breath. He denied aspirating any seawater. He borrowed his daughter's salbutamol inhaler and took a few puffs. He presented to his general practitioner about 90 minutes after the incident. The general practitioner heard crackles on his right side and referred him to hospital. He presented to the hospital 8-9 hours after the incident.

$\mathrm{He}$ is known to have had type 1 diabetes for 13 years treated with insulin. He is a non-smoker, drinks about 4 units of alcohol a week, and works as a pharmacist.

On admission to the ward, he was comfortable at rest. His blood pressure was $125 / 73 \mathrm{~mm} \mathrm{Hg}$, pulse $60 / \mathrm{min}$, and oxygen saturation $94 \%$ on room air. Jugular venous pressure was not raised, and there was no pedal oedema. There were crackles on the right side of the chest. Cardiovascular examination was normal with no murmur heard.

He improved quickly on the ward and was asymptomatic with no drugs prescribed.

\section{INVESTIGATIONS}

The following are the results of the investigations carried out.

- Haemoglobin, 146 g/l; white blood cell count, $9800 \times 10^{9} / \mathrm{l}$; platelet count, $230000 \times 10^{9} / 1$.

- Sodium, $141 \mathrm{mmol} / \mathrm{l}$ (normal range 135-145); potassium, $4.3 \mathrm{mmol} / \mathrm{l}$ (3.4-5.1); urea, $5 \mathrm{mmol} / \mathrm{l}(2.5-7.5)$; creatinine, $82 \mathrm{mmol} / \mathrm{l}(70-130)$.

- D-Dimer, $286 \mathrm{ng} / \mathrm{ml}$ (normal $<250 \mathrm{ng} / \mathrm{ml}$ ).

- Troponin I, 0.11 (normal <0.04).

- Electrocardiogram, sinus bradycardia.

- Chest radiograph, normal heart size, lung fields clear (performed about three hours after admission and about 12 hours after episode).
- Echocardiogram, mild left ventricular hypertrophy with good systolic function; "Whiff" of mitral regurgitation and tricuspid regurgitation detected.

- 24 hour cardiac monitoring, sinus rhythm with bradycardia throughout treadmill test; 15 minutes on Bruce protocol, asymptomatic throughout with maximal predicted heart rate and blood pressure achieved.

\section{PROGRESS}

The diagnosis was pulmonary oedema precipitated by swimming in cold water. The patient was still asymptomatic at follow up four weeks after his discharge.

The slight rise in troponin was thought to be due to cardiac strain resulting from the pulmonary oedema. As he has type 1 diabetes, microvascular changes could not be excluded. However, he declined further investigations such as a thallium scan or coronary angiography. He has returned to triathlon training with no ill effect.

\section{DISCUSSION}

Pulmonary oedema induced by swimming in cold water has previously been described in fit young men. Three cases were described in young men undergoing US Navy SEAL underwater demolition training. ${ }^{1}$ An Israeli study found that $60 \%$ of athletic swimmers had symptoms of pulmonary oedema. ${ }^{2}$ Another Israeli study found similar features in young men undergoing military fitness training. ${ }^{3}$

The following factors are thought to contribute to the temporary increase in capillary venous pressure.

- Exercise causes increased cardiac output.

- Excessive drinking of water before swimming, to counteract dehydration, causes increase in preload and pulmonary venous pressure.

- Swimming in cold water (even wearing a wet suit) can cause a decrease in core temperature resulting in redistribution of blood from peripheral to thoracic vessels resulting in a further increase in preload.

- Cold temperatures can also increase preload and after load as well as pulmonary vascular resistance. ${ }^{4}$

It has been reported that most patients do not have recurrence of symptoms. ${ }^{3}$ Owing to gravity dependent increases in pulmonary capillary pressure, signs are usually present on the right side (as in our patient).

Most patients improve quickly and spontaneously and do not require diuretics.

\section{Authors' affiliations \\ R Biswas, P K Shibu, C M James, Withybush Hospital, Haverfordwest, Wales, UK}

Correspondence to: Dr Biswas, Withybush Hospital, Fishguard Road, Haverfordwest SA61 2PZ, UK; rajabiswas@hotmail.com

Accepted 4 May 2004 


\section{REFERENCES}

1 Lund LK, Mahon RT, Tanen DA, et al. Swimming induced pulmonary edema. Ann Emerg Med 2003;41:251-6.

2 Shupak A, Weiler-Ravell D, Adir Y. Pulmonary oedema induced by strenuous swimming. Respir Physiol 2000;121:25-31.
3 Weiler-Ravell D, Shupak A, Goldenberg I, et al. Pulmonary oedema and haemoptysis induced by strenuous swimming. BMJ 1995;311 $361-2$.

4 Keatinge WR, Mcllroy MB, Goldfein A. Cardiovascular response to ice-cold showers. J Appl Physiol 1964;19:1145-50. 